\title{
EL Estado DE DERECHO Y LA CORTE INTERAMERICANA DE DERECHOS HuMANOS*
}

\author{
The Rule of LAW AND THE INTER- \\ American Court of Human Rights
}

\author{
O Estado de direito e a Corte \\ INTERAMERICANA DE DIREITOS \\ HuMANOS
}

\begin{abstract}
GONZALO CANDIA-FALCÓN**
* El presente artículo se enmarca dentro del proyecto de investigación "La teoría de los derechos implícitos en el derecho constitucional chileno y comparado. Estudio y análisis dogmático-constitucional" VRI 26/2014, patrocinado por la Vicerrectoría de Investigación de la Pontificia Universidad Católica de Chile. El autor, asimismo, agradece a Javiera Farías, alumna del programa de doctorado en derecho de la Pontificia Universidad Católica de Chile, y a Juan Lagos, estudiante de pregrado de la Facultad de Derecho de la Pontificia Universidad Católica de Chile, por la colaboración prestada en la elaboración de este artículo. Las traducciones son nuestras.

** Pontificia Universidad Católica de Chile. Chile. gfcandia@uc.cl.
\end{abstract}

RECIBIDO: 27 dE AGOSTO DE 2015. ENVÍo A PARES: 28 DE AGOSTO DE 2015 APROBAdo POR PARES: 12 DE OCTUBRE DE 2015. ACEPTADO: 13 DE OCTUBRE DE 2015 


\section{RESUMEN}

El artículo aborda la concepción de Estado de derecho, su aplicabilidad a nivel internacional y la visión que la Corte Interamericana de Derechos Humanos tiene respecto de este. Mediante un análisis crítico de la jurisprudencia interamericana, el autor reconoce cómo la Corte ha promovido los valores del Estado de derecho al interior de los Estados partes de la Convención Americana. Sin embargo, el trabajo también identifica áreas jurisprudenciales donde la propia Corte ha generado ciertas tensiones con los mismos estándares dispuestos por ella en relación con la idea de Estado de derecho en diversos ámbitos (doctrina de derechos implícitos, protección del derecho a la vida, reapertura de procesos penales, control de convencionalidad, recurso de revisión). Para superar estas tensiones, se sugiere reforzar la comprensión de la noción de Estado de derecho a nivel interamericano y, con ello, la relación virtuosa de reciprocidad que dicha noción implica.

\section{PALABRAS CLAVE}

Estado de derecho; legalidad; irretroactividad; reciprocidad; Corte Interamericana de Derechos Humanos. 


\section{ABSTRACT}

The article discusses the concept of the rule of law, its applicability at the international level, and the view of the Inter-American Court of Human Rights in that respect. Through a critical analysis of inter-American jurisprudence, the author acknowledges the way in which the Court has promoted the values of the rule of law in the states parties to the American Convention. However, the article also identifies areas of jurisprudence where the Court itself has generated a certain amount of tension surrounding the very same standards it has set concerning the rule of law in different legal spheres (e.g., doctrine of implied rights, protection of the right to life, reopening criminal proceedings, review for compliance and motion for review). To overcome these tensions, it is suggested our understanding of the concept of the rule of law at the inter-American level be reinforced and, hence, the virtuous relationship of reciprocity that notion implies.

\section{KEYWORDS}

Rule of law; legality; non-retroactivity; reciprocity; Inter-American Court of Human Rights. 


\section{RESUMO}

Este artigo aborda a concepção de Estado de direito, sua aplicabilidade no âmbito internacional e a visão que a Corte Interamericana de Direitos Humanos tem a respeito deste. Mediante uma análise crítica da jurisprudência interamericana, o autor reconhece como a Corte vem promovendo os valores do Estado de direito no interior dos Estados Partes da Convenção Americana. Contudo, o trabalho também identifica áreas jurisprudenciais em que a própria Corte tem gerado certas tensões com os mesmos padrões dispostos por ela quanto à ideia de Estado de direito em diversos âmbitos (doutrina de direitos implícitos, proteção do direito à vida, reabertura de processos penais, controle de convencionalidade, recurso de revista). Para superar essas tensões, sugere-se reforçar a compreensão da noção de Estado de direito no âmbito interamericano e, com isso, a relação virtuosa de reciprocidade que essa noção implica.

\section{PALAVRAS-CHAVE}

Estado de direito; legalidade; irretroatividade; reciprocidade; Corte Interamericana de Direitos Humanos. 
Sumario: Introducción; 1. Noción de Estado de derecho; 2. El Estado de derecho en el ordenamiento

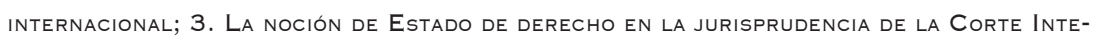
ramericana de Derechos humanos; 4. Estado de derecho y decisiones de la Corte idH; 4.1. El desarRollo de La doctrina de los derechos implícitos; 4.2. Los ESTÁndares de proTECCIÓN DEL DERECHO A LA VIDA; 4.3. La APERTURA DE PROCESOS PENALES FENECIDOS; 4.4. La CREACIÓN DEL CONTROL DE CONVENCIONALIDAD; 4.5. LA DISPONIBILIDAD DEL RECURSO DE REVISIÓN; 5. Corte idh y Estado de derecho: ¿hacia dónde avanzar?; Conclusiones; Bibliografía; JuRISPRUDENCIA CITADA.

\section{INTRODUCCIÓN}

El presente artículo tiene por objeto demostrar que: a) la Corte Interamericana de Derechos Humanos (en adelante, Corte IDH o "la Corte") ha conceptualizado en sus aspectos centrales los elementos básicos que configuran la noción de Estado de derecho y que, pese a ello, b) la propia Corte ha generado líneas jurisprudenciales que producen espacios de tensión con los mismos elementos descritos por el tribunal en (a).

Para ello se hará, en primer lugar, una rápida revisión de la noción básica de Estado de derecho y los elementos que lo constituyen, tales como el principio de legalidad y la idea de irretroactividad. En segundo lugar, se profundizará en torno a la idea de reciprocidad implícita dentro de la idea de Estado de derecho. Dicha relación de reciprocidad obliga a todos los actores de cualquier sistema jurídico, sea como autoridades o destinatarios de normas, a sujetar su actuación a derecho. En tercer lugar, se ofrecerán razones que justifican la aplicación de la idea de Estado de derecho al sistema jurídico internacional y a todos sus actores, principalmente Estados e instituciones como las cortes.

A partir de lo anterior, se describirá cómo la Corte IDH ha conceptualizado en su jurisprudencia la noción de Estado de derecho. Se indicará que, pese a existir pocas menciones directas al concepto en cuestión, la Corte ha esbozado el contenido de ciertos elementos que son centrales a la noción de Estado de derecho, tales como el principio de legalidad y la irretroactividad. En virtud de ello se sostendrá que la Corte, efectivamente, ha actuado en la promoción de la idea de Estado de derecho, imponiendo sus estándares a los Estados partes de la Convención Americana.

Sin embargo, se argumentará que, pese a los intentos de la Corte por promover los principios del Estado de derecho dentro de los Estados partes del sistema interamericano, la propia Corte IDH ha generado líneas jurisprudenciales que producen fuertes tensiones con aspectos esenciales de la noción de Estado de derecho que ella misma conceptualiza. Ello es observable en cinco áreas específicas: a) el desarrollo de la doctrina de los derechos implícitos; b) los estándares de protección del derecho a la vida; c) la apertura de procesos penales fenecidos; d) la creación del control de convencionalidad y e) la disponibilidad del recurso de revisión.

Frente a este escenario se concluirá que resulta altamente paradójico que la misma Corte que condena a los Estados por la infracción de principios fundamentales 
para el Estado de derecho, como los principios de legalidad e irretroactividad, no proceda a aplicar en puridad la totalidad de las exigencias que dichos estándares reclaman tratándose de la relación entre la Corte IDH y los Estados. Ello, claramente, no promueve una relación de reciprocidad entre los Estados y la Corte IDH, la que obliga a ambos a someterse estrictamente al derecho vigente.

Es, precisamente, el reforzamiento de la comprensión de la noción de Estado de derecho dentro del sistema interamericano de protección de los derechos humanos el que permitirá superar la paradoja anteriormente descrita. Desde una perspectiva conceptual, esto es perfectamente posible, porque la propia Corte IDH ha profundizado acerca de las exigencias que el Estado de derecho demanda de parte de los Estados. Así, volviendo a la doctrina desarrollada en torno a la noción que nos ocupa, en sus opiniones consultivas y decisiones contenciosas la Corte puede aliviar las tensiones creadas por ella misma a partir de las líneas jurisprudenciales problemáticas señaladas en el presente trabajo.

\section{NOCIÓN DE ESTADO DE DERECHO}

El Estado de derecho es una noción que, en sus términos más generales, exige la sujeción de la autoridad estatal a derecho. Ello aparece en contraposición con todo sistema en el cual la autoridad dispone de poderes omnímodos o de una discrecionalidad absoluta para resolver respecto de los asuntos públicos. ${ }^{1}$ En ese sentido, la noción de Estado de derecho busca imponer a toda autoridad una disciplina interna que permita generar un sistema legal que se encuentre "en buena forma". ${ }^{2}$ En ese contexto, se ha entendido tradicionalmente que el Estado de derecho se identifica con las condiciones bajo las cuales un sistema legal es capaz de funcionar adecuadamente. ${ }^{3}$

Los autores han elaborado distintas listas acerca de cuáles serían esas condiciones. Sin embargo, ellas tienden a converger pues, no obstante sus denominaciones, aspiran a un fundamento común respecto del buen funcionamiento del sistema en comento: la aptitud del ordenamiento jurídico para sujetar a la autoridad estatal y de esta para actuar conforme a aquel.

Así, por una parte, John Finnis indica que un ordenamiento jurídico representaría un Estado de derecho en la medida que sus normas: a) no tengan carácter retroactivo; b) sean susceptibles de ser cumplidas en la práctica por los ciudadanos; c) sean promulgadas públicamente; d) sean claras; e) sean coherentes las unas con las otras; f) tengan suficiente estabilidad para orientar a las personas en sus procesos de toma de decisiones; g) sean originadas en procedimientos predeterminados que, a su vez, sean claros, estables y de aplicación general; y h) que

1 Albert Venn Dicey, Introduction to the Study of the Constitution, 8 ed., Indianapolis, Liberty Fund, 1982, p. 120.

2 John FinNis, Natural Law and Natural Rights, 2 ed., Oxford, Oxford University Press, 2011, p. 270 (la traducción es nuestra).

3 Ibid., p. 270.

DÍKAION - ISSN 0120-8942 
las autoridades llamadas a legislar, administrar y aplicar el derecho i) sean jurídicamente responsables por sus actos y ii) que dichas autoridades administren el derecho de forma consistente y en conformidad a su tenor. ${ }^{4}$

Por otra parte, Lon Fuller indica que las condiciones que requiere un sistema jurídico para representar un Estado de derecho están asociadas con la existencia de: a) el carácter general de las normas; b) su promulgación; c) su irretroactividad; d) su claridad; e) su consistencia; f) el hecho que ellas puedan ser cumplidas, en la práctica, por sus destinatarios; y g) que exista una congruencia entre la actuación de la autoridad que administra el derecho y la normativa existente. ${ }^{5}$

Del mismo modo, las exigencias del Estado de derecho también tienen un aspecto institucional, relacionado con la existencia de procedimientos judiciales que permitan a las personas un adecuado acceso a cortes imparciales e independientes. Asimismo, el Estado de derecho exige instituciones políticas, legislativas y judiciales maduras, conscientes de sus propias responsabilidades. ${ }^{6}$

Muchos pueden ver en la enumeración señalada un exceso de formalismo jurídico, pues pareciera ser que el cumplimiento de los parámetros del Estado de derecho se limitara solo a una cuestión puramente procedimental. Sin embargo, dichas exigencias suponen la existencia de un modo virtuoso de relación entre los distintos miembros de la comunidad política.

Este "modo virtuoso" de relación tiene dos vertientes. La primera busca promover el ejercicio responsable de la libertad personal al permitir a los ciudadanos tomar decisiones acerca de sus vidas con un cierto grado de seguridad que es proveído por la claridad, la no retroactividad y la estabilidad de las normas jurídicas. ${ }^{7}$ Ello porque los ciudadanos solo pueden ejercer sus libertades de forma significativa dentro de contextos normativos en los cuales el derecho es posible de ser obedecido. ${ }^{8}$ En ese sentido, el ideal del Estado de derecho reconoce el valor de la dignidad de la persona y promueve el ejercicio responsable de su libertad dentro de la comunidad politica.

Por otro lado, el Estado de derecho supone también una relación de reciprocidad entre la autoridad y el ciudadano. Dicha relación implica, tal como Fuller lo indica, que así como los ciudadanos se sujetan al derecho dictado por la autoridad, la autoridad se sujeta a las exigencias del Estado de derecho que hacen posible el cumplimiento de las normas. En ese sentido, ambos —autoridad y ciudada-

Ibid., pp. 270-271.

Lon Fuller, The Morality of Law, 2 ed., New Haven, Yale University Press, 1964, pp. 46-91.

John FinNis, Natural Law and Natural Rights, op. cit., p. 271. Véase también Jeremy WALdron, "The rule of law and the importance of procedure", en James E. FlEming (editor), Getting to the rule of law, New York, New York University Press, 2011, p. 6.

7 John Finnis, Natural Law and Natural Rights, op. cit., p. 271.

8 Joseph RAz, "The rule of law and its virtue", en Joseph Raz (autor), The authority of law, 2 ed., Oxford, Oxford University Press, 2009, p. 213. 
no- se encuentran sujetos al derecho. ${ }^{9}$ Dicha sujeción pareciera promover otro valor: la igualdad radical entre las personas que ejercen el poder y quienes están sujetos a dicha autoridad. Ella justifica que ambos se sometan, aun cuando sea de formas diversas, al derecho. Esto es lo que precisamente algunos autores denominan principio de juridicidad. ${ }^{10}$

El propósito central perseguido por el Estado de derecho - la custodia de las condiciones que permiten ejercer responsablemente la libertad personal- muchas veces exigirá de las autoridades llamadas a administrar el derecho un sentido de disciplina institucional. Ello por cuanto los principios del estado de derecho tienen aplicación sistémica, esto es, "se aplican a todo lo largo y a todo lo ancho de todas las operaciones básicas de un sistema jurídico". ${ }^{11}$ Esto se hace particularmente importante en relación con la judicatura. Construcciones jurídicas impensadas, cambios jurisprudenciales radicales, o la deliberada infracción del principio de separación de poderes debilitan notablemente la relativa seguridad que los ciudadanos deben gozar para planificar sus vidas. ${ }^{12}$

En ese sentido, el Estado de derecho, al menos en su versión tradicional, impone restricciones a la autoridad estatal, particularmente en aquella área donde, por la naturaleza de su actividad, goza de un mayor ámbito de discrecionalidad. Ello porque en dichos espacios, o la discrecionalidad es limitada por la disciplina impuesta por el Estado de derecho, o bien esa discrecionalidad es absoluta. De allí que este concepto sea clave para el recto entendimiento de las potestades de las que dispone, por ejemplo, el poder ejecutivo y el juez. En efecto, el ejercicio de una discrecionalidad sin sujeción a ningún tipo de disciplina institucional repugna al Estado de derecho.

\section{El ESTADO DE DERECHO EN EL ORDENAMIENTO INTERNACIONAL}

En términos generales, se ha concebido al Estado de derecho como una noción con aplicación dentro de la esfera de los sistemas jurídicos nacionales. En ese contexto, existe una amplia discusión acerca de si la noción de Estado de derecho es aplicable a los sujetos de derecho internacional en sus relaciones vis a vis. La mayoría de los autores estima que los principios del Estado de derecho deben, al menos, regir dichas relaciones en la medida que ellos representan la primera autoridad legislativa en materia de derecho internacional. ${ }^{13}$ Por ejem-

9 Lon Fuller, The Morality of Law, op. cit., p. 39

10 Eduardo Sото-KLoss, Derecho Administrativo - Bases Fundamentales, Santiago de Chile, Editorial Jurídica de Chile, t. II, 1996, pp. 24-43.

11 Robert Summers, "Los principios del Estado de derecho", en Miguel Carbonell, Wistano Orozco y Rodolfo VÁşuez (coords.), Estado de derecho. Concepto, fundamentos y democratización en América Latina, Ciudad de México, Siglo XXI Editores, 2002, p. 44.

232 John FinNis, Natural Law and Natural Rights, op. cit., p. 272.

13 Para profundizar en torno a la aplicación de las exigencias de la noción de Estado de derecho en el ámbito internacional véase: Arthur WATTs, "The international rule of law", German Yearbook of International Law, 36 (1993), pp. 15-45; Simon Chesterman, “An international rule of law?”, Ameri- 
plo, Jeremy Waldron ha señalado que los elementos que configuran el Estado de derecho demandan que la actuación de los Estados sea respetuosa del derecho, incluso en sus interacciones a nivel internacional. ${ }^{14}$

En ese sentido, las limitaciones que el Estado de derecho impondría a los Estados en cuanto legisladores dentro de sus esferas de competencia a nivel doméstico no serían menores que las que el mismo Estado de derecho les exigiría en la esfera del derecho internacional. ${ }^{15}$ Esto, en la práctica, implicaría que los Estados, al momento de generar y administrar las normas jurídicas internacionales por ellos mismos promulgadas, deben operar de acuerdo con las exigencias del Estado de derecho. De alli que Samantha Besson afirme que "los procesos de creación de derecho internacional deben estar constituidos de forma tal que satisfagan algunas de las exigencias asociadas con el Estado de derecho en el ámbito internacional, particularmente las exigencias de claridad, publicidad, certeza, igualdad, transparencia e imparcialidad" ${ }^{16}$ En ese mismo sentido, las exigencias del Estado de derecho aplicadas en el ámbito del derecho internacional acentúan su normatividad lo que, simultáneamente, permite promover la autoridad, eficacia y legitimidad de esta área del derecho. ${ }^{17}$

Ahora bien, los desarrollos del derecho internacional han generado una serie de instituciones que, con el tiempo, han terminado convirtiéndose en sujetos de derecho internacional, con grados de autoridad diversos en distintas áreas. Una de esas instituciones son los tribunales supranacionales de derechos humanos, tales como la Corte IDH o el Tribunal Europeo de Derechos Humanos, que disponen de grados de autoridad relevante en el ámbito del derecho internacional de los derechos humanos.

En ese contexto, este trabajo asume que la noción de Estado de derecho tiene algo qué decir no solo en el ámbito de las relaciones normativas entre los Estados a nivel internacional, sino que también es relevante al momento de analizar la forma como las instituciones internacionales actúan dentro de la esfera de autoridad reconocida por los Estados. Desde esa perspectiva, el Estado de derecho se plantea como un mecanismo que busca establecer un orden de relación virtuoso entre Estados y tribunales regionales de derechos humanos, en la medida que ellos representan órganos llamados a administrar normas jurídicas. Dicho mecanismo permite

can Journal of Comparative Law, 56 (2008), pp. 331-362; James CRAWFORD, "International law and the rule of law", Adelaide Law Review, 24 (3) (2003), pp. 3-12; Mattias Kumm, "The international rule of law and the limits of the internationalist model", Virginia Journal of International Law, 44 (2003-2004), pp. 19-32.

14 Jeremy WaLdRon, "The rule of international law", Harvard Journal of Law \& Public Policy, 30 (1) (2006), pp. 15-30. En relación con los límites de aplicación de los principios del Estado de derecho a los Estados véase: Jeremy WALDRon, "Are sovereign entitled to the benefit of the international rule of law?”, The European Journal of International Law, 22 (2) (2011), pp. 315-343.

15 Jeremy WALDRon, "The rule of international law", op. cit., pp. 21-25.

16 Samantha Besson, "Theorizing the sources of international law", en Samanta BEsson y John TASIOULAS (eds.), The philosophy of international law, Oxford, Oxford University Press, 2012, p. 172.

17 Jean D'Aspremont, Formalism and the sources of international law, Oxford, Oxford University Press, 2011, p. 29. 
que emerja una relación en la cual tanto los Estados como dichos tribunales se reconocen limitados por la supremacía del derecho, similar en cierto modo a la relación virtuosa entre los miembros de una comunidad política a nivel nacional. Lo anterior es particularmente relevante en un contexto normativo complejo. En efecto, el derecho internacional no representa el caso focal de un sistema jurídico en la medida que él mismo carece de una autoridad central llamada a dictar y a ejecutar las normas jurídicas. ${ }^{18}$ De hecho, es un sistema profundamente fragmentado en su aplicación, por cuanto los distintos cuerpos normativos que lo integran suelen ser aplicados por cortes especializadas, las cuales buscan aplicar su derecho sin necesariamente considerar las consecuencias que ellas traen aparejadas en otras áreas del derecho internacional. Esta fragmentación, evidentemente, resta coherencia al sistema de derecho internacional. ${ }^{19}$ Por otro lado, muchas veces es dificil distinguir dentro del sistema jurídico internacional entre normas jurídicas propiamente tales, vinculantes para todos los actores, y aquellas que representan instancias de soft law. Esto, claramente, hace más dificil a los actores del sistema poder orientar sus comportamientos y, por tanto, asumir sus obligaciones internacionales. ${ }^{20}$

Particularmente, tratándose en especial de las normas de derecho internacional de los derechos humanos, es posible encontrar estándares amplios y textualmente indeterminados contenidos en las convenciones cuya aplicación es delegada por los Estados en ciertos órganos, como las cortes internacionales de derechos humanos. Dichos estándares, en su indeterminación semántica, permiten a estas cortes el ejercicio de amplios márgenes de discrecionalidad. Es aquí donde el Estado de derecho es especialmente requerido, por cuanto impone al ente administrador del derecho una disciplina que permite que el ejercicio de esa discrecionalidad sea, precisamente, limitada.

Asimismo, la aplicación de la noción de Estado de derecho en el ámbito del derecho internacional promueve una relación virtuosa de reciprocidad entre todos los actores del sistema. En efecto, la aplicación de la noción de Estado de derecho obliga a todos los operadores del sistema -Estados e instituciones internacionales- a sujetarse al derecho sin que ninguno de ellos tenga una posición de privilegio al respecto. Dentro de ese modelo, los Estados deben someterse a las decisiones de los tribunales a quienes confieren jurisdicción ${ }^{21} \mathrm{y}$, de igual forma, las cortes internacionales deben someterse en su actividad interpretativa y creadora al derecho producido por los propios Estados y a sus expectativas al momento de dar vida al tratado que les confirió existencia.

18 H.L.A. HART, The Concept of Law, 2 ed., Oxford, Oxford University Press, 1994, pp. 213-232.

19 Guillaume Gilbert, "The Profileration of International Judicial Bodies: The Outlook for the International Legal Order", Corte Internacional de Justicia, 2000, en http://www.icj-cij.org/court/index.

234 php?pr=85\&pt=3\&p1=1\&p2=3\&p3=1, fecha de consulta: 21 de agosto de 2015.

20 Jean D'Aspremont, Formalism and the sources of international law, op. cit., p. 30.

21 Carlos Ayala, "La ejecución de sentencias de la Corte Interamericana de Derechos Humanos", Estudios Constitucionales, año 5 (1) (2007), p. 133. 
En sintesis: la aplicación de la noción de Estado de derecho en el ámbito del derecho internacional permite salvaguardar valores claves para todo sistema jurídico, en un contexto normativo altamente complejo como lo es el derecho internacional de los derechos humanos.

\section{LA NOCIÓN DE ESTADO DE DERECHO EN LA JURISPRUDENCIA DE LA CORTE INTERAMERICANA DE DERECHOS HUMANOS}

La Convención Americana sobre Derechos Humanos (en adelante, Pacto de San José o la Convención) protege elementos fundamentales del Estado de derecho en términos de garantías. Por ejemplo, el artículo 7 establece que nadie puede ser privado de su libertad sin que la detención sea conforme a derecho y sin que la legalidad de la misma pueda ser evaluada ante una autoridad judicial. Asimismo, el artículo 8 describe una serie de limitaciones a la autoridad estatal al momento de juzgar delitos. Por otro lado, el artículo 9 reconoce los principios de irretroactividad y de legalidad penal. Además, la Convención exige que las restricciones aplicables a los derechos reconocidos en la misma sean establecidas a través de leyes dictadas para salvaguardar el interés general (art. 30) y conformes a las "justas exigencias del bien común” (art. 32.2). Por último, la Convención también obliga a los Estados a asegurar los derechos de las personas sin importar "raza, color, sexo, idioma, religión, opiniones políticas o de cualquier otra índole, origen nacional o social, posición económica, nacimiento o cualquier otra condición social" (art. 1.1).

La Corte IDH no ha referido con profusión el significado y las implicancias de la noción de Estado de derecho. Sin embargo, las pocas veces en que la Corte se ha referido directamente a la misma, lo ha hecho reforzando tres aspectos o ideas centrales: legalidad, irretroactividad y debido proceso.

Sobre el primer aspecto, la Corte IDH ha enfatizado la idea de que los Estados deben sujetar su actuación al principio de legalidad. Por tanto, "la creación de las normas jurídicas de carácter general ha de hacerse de acuerdo con los procedimientos y por los órganos establecidos en la constitución de cada Estado parte, y a él deben ajustar su conducta de manera estricta todas las autoridades públicas”. ${ }^{22}$ De este modo, toda actuación normativa que busque restringir derechos fundamentales, por ejemplo, debe proceder a través de la ley, entendida aquella como una actuación del poder legislativo. ${ }^{23}$ Ello por cuanto corresponde que los Estados armonicen el ejercicio de los distintos derechos estableciendo con claridad "las responsabilidades y sanciones que fueren necesarias para obtener

22 Corte IDH, "La Expresión 'Leyes' en el artículo 30 de la Convención Americana sobre Derechos Humanos”, Opinión Consultiva OC-6/86 del 9 de mayo de 1986, Serie A No. 6, 1986, párrafo 32. Ibid., párrafo 31 . 
tal propósito". ${ }^{24}$ Adicionalmente, la reserva de ley en materia de regulación de derechos fundamentales "constituye un obstáculo importante para el ejercicio arbitrario del poder" ${ }^{25}$ Incluso, la suspensión de garantías autorizada por el artículo 27 de la Convención "no significa [...] que [ella] comporte la suspensión temporal del Estado de derecho o que autorice a los gobernantes a apartar su conducta de la legalidad a la que en todo momento deben ceñirse". ${ }^{26}$

En relación con lo anterior, la Corte IDH ha establecido que las obligaciones que impone la legalidad respecto de los Estados en relación con los derechos fundamentales no se agotan en el solo establecimiento de limitaciones al ejercicio de los mismos por la ley. Por el contrario, dicha ley, además, debe cumplir con cierta calidad técnica. Por ejemplo, tratándose del ejercicio de la libertad personal, la Corte IDH ha indicado que no solo las causas y los procedimientos que permiten la privación de libertad de las personas deben encontrarse definidos por la ley, sino que además el tribunal ha exigido que esa ley cumpla con ciertas características específicas. En efecto, las normas legales que afectan la libertad personal deben ser redactadas de forma tal que las mismas generen grados mínimos de previsibilidad en sus destinatarios. ${ }^{27}$

Lo mismo ocurre en el ámbito de la tipicidad. Así, la jurisprudencia permanente de la Corte IDH ha enfatizado que las acciones $u$ omisiones objeto de penalización deben ser formuladas "en forma expresa, precisa, taxativa y previa", ${ }^{28}$ todo ello para "brindar seguridad jurídica al ciudadano". ${ }^{29}$ De alli que la Corte rechace la elaboración de tipos penales ambiguos, en la medida que los mismos "abre[n] el campo al arbitrio de la autoridad". ${ }^{30}$ La Corte específicamente ha cuestionado el ejercicio abusivo de la discrecionalidad estatal en la administración de las normas, particularmente en el ámbito penal, donde condenó a un Estado por la existencia de normas que permitirian al juez efectuar un control de peligrosidad de un individuo. ${ }^{31}$

En relación con el segundo aspecto, la Corte IDH también ha enfatizado el valor de la prospectividad de las normas jurídicas. Esto en razón de que "en un Estado

24 Corte IDH, "Caso Tristán Donoso vs. Panamá, Excepción Preliminar, Fondo, Reparaciones y Costas”, Sentencia de 27 de enero de 2009, Serie C No. 193, 2009, párrafo 112.

25 Gabriela Rodríguez, "Artículo 30. Alcance de las restricciones", en Christian Steiner y Patricia URIBE (eds.), Comentario Convención Americana sobre Derechos Humanos, Bolivia, Konrad Adenauer Stiftung, 2014, p. 717.

26 Corte IDH, "El Hábeas Corpus Bajo Suspensión de Garantías (arts. 27.2, 25.1 y 7.6 Convención Americana sobre Derechos Humanos)", Opinión Consultiva OC-8/87 del 30 de enero de 1987, Serie A No. 8, 1987, párrafo 24.

27 Corte IDH, “Caso Torres Millacura y otros vs. Argentina. Fondo, Reparaciones y Costas”, Sentencia de 26 de agosto de 2011, Serie C No. 229, párrafos 79-80.

28 Corte IDH, "Caso Usón Ramírez vs. Venezuela. Excepción Preliminar, Fondo, Reparaciones y Costas”, Sentencia de 20 de noviembre de 2009, Serie C No. 207, 2009, párrafo 55.

29 Ibid., párrafo 55.

23630 Corte IDH, “Caso Kimel vs. Argentina. Fondo, Reparaciones y Costas”, Sentencia de 2 de mayo de 2008, Serie C No. 177, 2008, párrafo 63.

31 Corte IDH, “Caso Fermín Ramírez vs. Guatemala. Fondo, Reparaciones y Costas”, Sentencia de 20 de junio de 2005, Serie C No. 126, 2005, párrafo 94. 
de derecho, los principios de legalidad e irretroactividad presiden la actuación de todos los órganos del Estado, en sus respectivas competencias”. ${ }^{32}$ En ese sentido, la Corte ha sostenido que "es indispensable que la norma punitiva, sea penal o administrativa, exista y resulte conocida, o pueda serlo, antes de que ocurran la acción u omisión que la contravienen y que se pretende sancionar". ${ }^{33}$ Ello por cuanto sin esa especificación, "los particulares no podrian orientar su comportamiento conforme a un orden jurídico vigente y cierto". ${ }^{34}$ Esa es la razón por la cual la Corte IDH condenó, por ejemplo, al Perú en aquellos casos en que algunos de sus ciudadanos fueron condenados por delitos de terrorismo establecidos con posterioridad a la comisión del acto delictivo. ${ }^{35}$ Misma cosa ocurrió respecto de Panamá en relación con la aplicación de una sanción administrativa de naturaleza retroactiva. ${ }^{36}$

Un tercer aspecto de Estado de derecho que la Corte IDH enfatiza es la garantía jurisdiccional como mecanismo de control de los actos del poder ejecutivo o la administración del Estado. Es por ello que dichos recursos deben estar disponibles y ser efectivos tanto en tiempos de normalidad como en situaciones extraordinarias. ${ }^{37}$ Ellos apuntan, en cuanto instrumentos del Estado de derecho, a "preservar la legalidad en una sociedad democrática". ${ }^{38}$ Es por eso que toda autorización administrativa o legislativa destinada a negar el acceso al recurso de habeas corpus, por ejemplo, es incompatible con la Convención Americana. ${ }^{39}$ Asimismo, la Corte IDH ha reforzado la idea de que los órganos del Estado deben sujetar su actuar a la ejecución de las sentencias de los tribunales, señalando que en todo sistema jurídico fundado en la noción de Estado de derecho "todas las autoridades públicas, dentro del marco de su competencia, deben atender las decisiones judiciales, así como dar impulso y ejecución a las mismas sin obstaculizar el sentido y alcance de la decisión ni retrasar indebidamente su ejecución". ${ }^{40}$

Como se aprecia, las pocas veces en que la Corte IDH se ha referido directamente la noción de Estado de derecho, lo ha hecho para enfatizar la conexión entre dicho concepto y la limitación del poder. Ello exige por parte de los Estados el respeto del principio de legalidad, de irretroactividad y del debido proceso legal. Todos ellos buscan hacer realidad el propósito esencial del Estado de derecho, que no es otro

32 Corte IDH, “Caso Baena Ricardo y otros vs. Panamá. Fondo, Reparaciones y Costas”, Sentencia de 2 de febrero de 2001, Serie C No. 72, 2001, párrafo 107.

33 Ibid., párrafo 106.

34 Idem.

35 Corte IDH, "Caso García Asto y Ramírez Rojas Vs. Perú”, Sentencia de 25 de noviembre de 2005, Serie C No. 137, 2005, párrafos 207-208.

36 Corte IDH, "Caso Baena Ricardo y otros Vs. Panamá. Fondo, Reparaciones y Costas”, cit., párrafo 115.

37 Corte IDH, “Caso Castillo Petruzzi y otros vs. Perú. Fondo, Reparaciones y Costas”, Sentencia de 30 de mayo de 1999, Serie C No. 52, 1999, párrafo 32.

38 Corte IDH, "El Hábeas Corpus Bajo Suspensión de Garantías (arts. 27.2, 25.1 y 7.6 Convención Americana sobre Derechos Humanos)”, cit., párrafo 42.

39 Ibid., párrafo 43.

40 Corte IDH, "Caso Furlan y Familiares vs. Argentina. Excepciones Preliminares, Fondo, Reparaciones y Costas”, Sentencia de 31 de agosto de 2012, Serie C No. 246, 2012, párrafo 212. 
sino imponer un limite, una disciplina interna al actuar normativo, creativo e interpretativo del derecho por parte de los Estados.

\section{Estado de derecho y decisiones de la CoRTE IDH}

Tal como se señaló, el Estado de derecho implica una relación de reciprocidad. Dicha reciprocidad exige que todos los actores que participan de un mismo sistema jurídico se sujeten por igual al derecho, sin generar privilegios en favor de uno u otro. En ese sentido, el Estado de derecho exige que tanto los productores, administradores y ejecutores de las normas jurídicas como sus destinatarios se sujeten al derecho. Solo así se puede hacer realidad ese modo de actuar virtuoso que dicha noción conlleva.

Tratándose del sistema interamericano de derechos humanos, y entendiendo que las condicionantes impuestas por el Estado de derecho aplican en este contexto, tanto los Estados como la Corte IDH están llamados a sujetar su actuación a la disciplina del Estado de derecho, con todos los requerimientos que este exige. De esta forma, los Estados están llamados a sujetar su acción al derecho dictado por ellos mismos a través de la Convención Americana y a cumplir las sentencias de la Corte IDH que aplican el tratado. Pero, al mismo tiempo, la propia Corte está llamada a ajustar su actuación interpretativa y creativa al derecho otorgado por los Estados, haciéndose cargo de las expectativas que ellos mismos tenían al momento de la promulgación de la Convención.

En relación con las actuaciones de la Corte IDH, no cabe duda alguna que ellas han promovido el establecimiento del rule of law en momentos particularmente complejos para Latinoamérica. Así, la Corte ha actuado impulsando los valores propios del Estado de derecho al condenar a los Estados por: a) las violaciones masivas de derechos humanos esenciales cometidas durante los regimenes militares o autoritarios en el continente; ${ }^{41}$ b) la aplicación retroactiva de normas sancionatorias; ${ }^{42}$ c) la infracción de la legalidad penal; ${ }^{43}$ d) la práctica de expropiaciones sin el pago de las correspondientes indemnizaciones; ${ }^{44}$ y e) la violación de las normas propias del debido proceso legal. ${ }^{45}$ Asimismo, la Corte IDH ha promovido los valores del Estado de derecho al sancionar en múltiples ocasiones la actuación de Estados como Venezuela que, bajo el signo de gobiernos autoritarios, buscan limitar la imparcialidad de los jueces nacionales. ${ }^{46}$

41 V. gr. Corte IDH, "Caso Velásquez Rodríguez vs. Honduras. Fondo", Sentencia de 29 de julio de 1988, Serie C No. 4, 1988.

42 V. gr. Corte IDH, "Caso Baena Ricardo y otros vs. Panamá. Fondo, Reparaciones y Costas”, cit.

43 V. gr. Corte IDH, "Caso Castillo Petruzzi y otros vs. Perú. Fondo, Reparaciones y Costas", cit.

44 V. gr. Corte IDH, "Caso Salvador Chiriboga vs. Ecuador. Excepción preliminar y Fondo”, Sentencia de 6 de mayo de 2008, Serie C No. 179, 2008.

45 V.gr. Corte IDH, “Caso López Álvarez vs. Honduras. Fondo, Reparaciones y Costas”, Sentencia de

$23846 \quad$ V.gr. Corte IDH, "Caso Apitz Barbera y otros ("Corte Primera de lo Contencioso Administrativo”) vs. Venezuela. Excepción Preliminar, Fondo, Reparaciones y Costas”, Sentencia de 5 de agosto de 2008, Serie C No. 182, 2008. 
Sin embargo, existen ciertas actuaciones de la Corte que generan espacios de tensión en relación con aquello que la propia Corte IDH ha reconocido como elementos esenciales del Estado de derecho, tales como los principios de legalidad e irretroactividad. Ello, particularmente, en casos que involucran: a) el desarrollo de la doctrina de los derechos implícitos; b) la protección del derecho a la vida; c) la apertura de procesos penales fenecidos; d) la creación del control de convencionalidad y e) la disponibilidad del recurso de revisión de las sentencias dictadas por la propia Corte IDH. Efectivamente, en estos casos podemos observar cierta tensión entre lo que dispone la Corte y las condiciones impuestas por la noción de Estado de derecho que la misma ha reconocido en sus fallos.

\subsection{El desarrollo de la doctrina de los derechos implícitos}

La Corte IDH, progresivamente, ha desarrollado la doctrina de los derechos implícitos. Esta doctrina propugna la idea de que el catálogo de derechos mencionados en la Convención no es taxativo, sino que se encuentra abierto a nuevas adiciones de derechos por vía judicial. Para algunos autores, la fuente normativa de esa potestad implícita de la Corte es el artículo 29 letra c) de la Convención, ${ }^{47}$ norma que indica que no cabe efectuar ninguna interpretación del tratado que excluya "otros derechos y garantías que son inherentes al ser humano o que se derivan de la forma democrática representativa de gobierno”.

Siguiendo esta doctrina, la Corte IDH ha incorporado al catálogo de derechos enumerados en la Convención nuevos derechos, tales como: a) el derecho a la verdad y a la efectiva sanción penal; ${ }^{48}$ b) el derecho a la propiedad comunal indígena; ${ }^{49}$ c) el derecho al acceso a la identidad biológica de los progenitores; ${ }^{50} \mathrm{y}$ d) los denominados derechos reproductivos-sexuales. ${ }^{51}$ La Corte ha procedido a ello a partir de "interpretaciones" de las normas de derechos contenidos en la propia Convención, señalando que los derechos implícitos representan exigencias necesarias y no posibles de los derechos enumerados. Sin embargo, esa visión, un poco ingenua, contrasta con lo manifestado por autores como Laurence Burgorgue-Larsen, quien afirma que el reconocimiento de derechos implícitos en la Convención por parte de la Corte "[se] trata, ni más ni menos, que de [una actuación destinada a] crear

47 Héctor Gros Espiell, "Los derechos humanos no enunciados o no enumerados en el constitucionalismo americano y en el artículo 29.c) de la Convención Americana sobre Derechos Humanos", Anuario Iberoamericano de Justicia Constitucional, 4 (2000), pp. 145-173.

48 El primer fallo jurisprudencial que recoge esta idea es: Corte IDH, "Caso Velásquez Rodríguez vs. Honduras. Fondo”, Sentencia de 29 de julio de 1988, Serie C No. 4, 1988. La noción se reitera en Corte IDH, "Caso Almonacid Arellano y otros vs. Chile. Excepciones Preliminares, Fondo, Reparaciones y Costas”, Sentencia de 26 de septiembre de 2006, Serie C No. 154, 2006, párrafos 147-150.

49 Corte IDH, "Caso de la Comunidad Mayagna (Sumo) Awas Tingni vs. Nicaragua. Fondo, Reparaciones y Costas”, Sentencia de 31 de agosto de 2001, Serie C No. 79, 2001, párrafo 148.

50 Corte IDH, "Caso Gelman vs. Uruguay. Fondo y Reparaciones", Sentencia de 24 de febrero de 2011, Serie C No. 221, 2011, párrafo 122.

51 Corte IDH, "Caso Artavia Murillo y otros (Fecundación in vitro) vs. Costa Rica. Excepciones Preliminares, Fondo, Reparaciones y Costas”, Sentencia de 28 noviembre de 2012, Serie C No. 257, 2012, párrafos 146-150. 
nuevos derechos", ${ }^{52}$ cuestión que aparece justificada por el hecho de que los jueces "gozan de una considerable laxitud para ejercer sus funciones creativamente ${ }^{53}$ en el campo del derecho internacional de los derechos humanos. En ese contexto, la estrategia adoptada por la Corte IDH resulta "particularmente astuta" 54 al vincular "sistemáticamente estos nuevos derechos a uno o más fundamentos jurídicos preexistentes en el seno de la Convención Americana”. ${ }^{55}$

Sin embargo, es la propia Corte la que en ciertas ocasiones ha reconocido que el reconocimiento de derechos implícitos en la Convención implica no una labor interpretativa, sino creativa por parte de los jueces interamericanos. En efecto, tratándose del derecho a la verdad y a la sanción penal efectiva, la Corte IDH manifestó que el mismo "es un derecho no existente en la Convención Americana" ${ }^{56}$ pese a lo cual terminó incorporándolo como tal. Igual cosa ocurrió respecto del derecho a la identidad biológica, garantía que la propia Corte IDH señaló que no era uno de aquellos enumerados por la Convención Americana. ${ }^{57}$ Sin embargo, la Corte terminó por incorporarlo tácitamente al tratado.

La problemática alrededor de los derechos implícitos está relacionada con la afectación de dos elementos que la propia Corte IDH ha señalado como esenciales para el resguardo del Estado de derecho: legalidad e irretroactividad. ${ }^{58}$

En primer lugar, la propia Corte ha señalado, respecto de los Estados, que toda modificación normativa debe ir de la mano de los procedimientos y de las instituciones que el propio derecho establece con antelación. Ello es absolutamente consistente con la idea de Estado de derecho, que exige que "los cambios en el derecho [...] [se lleven a cabo] mediante procedimientos apropiados, por instituciones, autoridades o personas debidamente autorizados para ello" . ${ }^{9}$ "De hecho, la propia Convención Americana establece con claridad quiénes están dotados de autoridad suficiente para modificar el tratado y los mecanismos de reforma que permiten incorporar nuevos derechos al catálogo del mismo. Así, el artículo 31 del tratado, bajo el epígrafe "reconocimiento de otros derechos", afirma que existe la posibilidad de que otros derechos y libertades sean incluidos en el "régimen de protección de esta Convención”. Sin embargo, esa incorporación debe ser efectuada "de acuerdo con los procedimientos establecidos en los artículos 76

52 Laurence Burgorgue-LaRsen, "El contexto, las técnicas y las consecuencias de la interpretación de la Convención Americana de Derechos Humanos”, Estudios Constitucionales, año 12 (1) (2014), p. 125.

53 Cecilia Medina, "The role of international tribunals: law-making or creative interpretation", en Dinah Shelton (ed.), The Oxford Handbook of International Human Rights Law, Oxford, Oxford University Press, p. 651 (la traducción es nuestra).

54 Laurence Burgorgue-Larsen, "El contexto, las técnicas y las consecuencias de la interpretación de la Convención Americana de Derechos Humanos”, op. cit., p. 125.

55 Ibid., p. 125.

56 Corte IDH, "Caso Castillo Páez vs. Perú. Fondo”, Sentencia de 3 de noviembre de 1997, Serie C No. 34, 1997, párrafo 86.

57 Corte IDH, “Caso Gelman vs. Uruguay. Fondo y Reparaciones”, cit., párrafo 122.

24058 Para un análisis más extenso del tema véase: Gonzalo CANDIA, "Derechos implícitos y Corte Interamericana de Derechos Humanos: una reflexión a la luz de la noción de Estado de derecho”, Revista Chilena de Derecho, 42 (3) (2015), pp. 873-902.

59 Robert Summers, "Los principios del Estado de derecho", op. cit., p. 40. 
y 77" de la misma Convención Americana. Dicho procedimiento necesariamente involucra la participación de los propios Estados. ${ }^{60}$

Sin embargo, en los hechos, la Corte IDH ha modificado unilateralmente la Convención por medio de la adición jurisprudencial de nuevos derechos a la misma. Esto no parece, precisamente, ajustarse al principio de legalidad, tan caro para la propia Corte y para la noción misma del Estado de derecho.

En segundo lugar, el desarrollo de la noción de derechos implicitos también atenta contra el principio de irretroactividad, garantía esencial del Estado de derecho. La propia Corte, como se explicó, concibió la irretroactividad como elemento fundante de la legitimidad de la actuación de los Estados respecto de sus nacionales, especialmente en el ámbito sancionatorio. Pues bien, si aceptamos que la noción de Estado de derecho implica una relación de reciprocidad entre los diversos actores de un sistema jurídico, entonces tanto la Corte IDH como los Estados se encuentran sujetos a la prohibición de imponer condenas de naturaleza retroactiva.

Ahora bien, el reconocimiento de un derecho, y de un derecho implícito en particular, va siempre acompañado de una obligación correlativa respecto de los Estados, la que puede ser una obligación de hacer o no hacer. ${ }^{61}$ En ese contexto, cuando la Corte sanciona a un Estado por la infracción de un derecho implícito, lo que en la práctica hace es condenarlo por el incumplimiento de una obligación. Sin embargo, tratándose de obligaciones derivadas de derechos implícitos, el Estado no tenía la posibilidad conceptual de asumir la ejecución de esa obligación en el pasado dado que, simplemente, la desconocía. De allí que la retroactividad de la condena, en este caso particular, importa la afectación de un elemento adicional del Estado de derecho: la posibilidad de que "las conductas exigidas por el derecho (...) [puedan ser cumplidas] por los destinatarios de las normas". ${ }^{62}$

En el ámbito del derecho internacional, la irretroactividad es un valor importante por un factor adicional. En el derecho internacional los principales actores normativos son los propios Estados: ellos son la fuente y los destinatarios del derecho, en la medida que el derecho internacional sigue siendo un derecho de fuente primariamente contractual. ${ }^{63}$ En ese contexto, parece del todo lógico que las cortes internacionales sancionen a los Estados por el incumplimiento de obligaciones que ellos mismos generaron. Sin embargo, si los Estados son sancionados por el incumplimiento de obligaciones respecto de las cuales ellos no consintieron y no tuvieron la posibilidad de ejecutar en el pasado, entonces existe una infracción del principio de irretroactividad y del principio que exige que toda norma jurídica debe ser aplicable

60 En efecto, de acuerdo con el artículo 76 de la Convención, el órgano llamado a introducir enmiendas a la Convención no es la Corte IDH, sino los propios Estados a través de la Asamblea General de la Organización de Estados Americanos. Asimismo, el artículo 77 de la Convención autoriza a los Estados para generar protocolos adicionales que permitan "incluir progresivamente en el régimen de protección [del sistema interamericano] [...] otros derechos y libertades".

61 John FinNis, Natural Law and Natural Rights, op. cit., pp. 200-201.

62 Robert Summers, "Los principios del Estado de derecho", op. cit., p. 39.

63 Antonio CASSESE, International Law, Oxford, Oxford University Press, 2005, p. 4. 
por sus destinatarios, no pudiendo aplicarse aquello que se desconoce actual o potencialmente.

En conclusión, el desarrollo de la doctrina de los derechos implícitos plantea tensiones severas con dos elementos fundantes de la noción de Estado de derecho: el principio de legalidad y de irretroactividad.

\subsection{Los estándares de protección del derecho a la vida}

La Corte IDH ha modificado sus parámetros de protección del derecho a la vida recientemente. En un principio, la Corte planteó que el derecho a la vida era un valor esencial para todo sistema de derechos humanos y, por tanto, la infracción del mismo no podía ser justificada o ponderada respecto de otros valores como la seguridad nacional. ${ }^{64}$ Por tanto, respecto del derecho a la vida "no [eran] admisibles enfoques restrictivos del mismo". ${ }^{65}$ Aún más, la Corte siempre señaló que "al no ser respetado el derecho a la vida, todos los derechos carecen de sentido". ${ }^{66}$ Por último, la propia Corte siempre reconoció que los Estados no solo tenían la obligación de evitar atentados contra el derecho a la vida, sino también que tenían la obligación de adoptar todas las medidas necesarias "para que no se produzcan violaciones de ese derecho básico" ${ }^{67}$ Finalmente, los Estados "deb[ían] crear un marco normativo adecuado que disuada cualquier amenaza del derecho a la vida". ${ }^{68}$

Sin embargo, esa doctrina cambió en Artavia Murillo vs. Costa Rica (2012), caso en el cual la Corte IDH consideró que el derecho a la vida representaba un valor jurídico más y, como tal, susceptible de ser ponderado respecto de otros valores distintos, tales como el derecho a la privacidad. Ello en la medida que "la finalidad del artículo 4.1 de la Convención es la de salvaguardar el derecho a la vida sin que ello implique la negación de otros derechos que protege la Convención" ${ }^{69}$ Por tanto, debería entenderse que el derecho a la vida no es un derecho absoluto dado que "[su] alegada protección [no] pued[e] justificar la negación total de otros derechos". ${ }^{70}$

La nueva visión planteada por la Corte IDH en Artavia Murillo respecto del estándar de revisión de infracciones del derecho a la vida es contradictoria con aquella señalada por la propia Corte en casos anteriores. En efecto, mientras antes del

64 Corte IDH, “Caso Velásquez Rodríguez vs. Honduras. Fondo”, Sentencia de 29 de julio de 1988, Serie C No. 4, 1988, párrafo 154.

65 Corte IDH, "Caso de los 'Niños de la Calle' (Villagrán Morales y otros) vs. Guatemala. Fondo”, Sentencia de 19 de noviembre de 1999, Serie C No. 63, 1999, párrafo 144.

66 Corte IDH, "Caso Juan Humberto Sánchez vs. Honduras. Excepción Preliminar, Fondo, Reparaciones y Costas”, Sentencia de 7 de junio de 2003, Serie C No. 99, 2003, párrafo 110.

67 Corte IDH, “Caso de los 'Niños de la Calle' (Villagrán Morales y otros) vs. Guatemala. Fondo”, cit., párrafo 144 .

68 Corte IDH, "Caso Montero Aranguren y otros (Retén de Catia) vs. Venezuela. Excepción Preliminar, Fondo, Reparaciones y Costas”, Sentencia de 5 de julio de 2006, Serie C No. 150, párrafo 75.

24269 Corte IDH, "Caso Artavia Murillo y otros (Fecundación in vitro) vs. Costa Rica. Excepciones Preliminares, Fondo, Reparaciones y Costas”, cit., párrafo 258.

70 Corte IDH, "Caso Artavia Murillo y otros (Fecundación in vitro) vs. Costa Rica. Excepciones Preliminares, Fondo, Reparaciones y Costas”, cit., párrafo 258. 
año 2012 la garantía del derecho a la vida era vista como un valor absoluto en la medida que establecía un limite infranqueable a la acción del estado, a partir de la sentencia de Artavia Murillo el carácter absoluto del derecho a la vida desaparece y, por tanto, el mismo se abre a interpretaciones de carácter proporcionalista.

La problemática de Estado de derecho en este ejemplo está representada por la introducción de un criterio relevante de análisis judicial que quiebra las certezas que la propia Corte había creado en el pasado. En efecto, tratándose de la aplicación de criterios judiciales de revisión, conviene que los mismos tengan una cierta permanencia en el tiempo para orientar a los diversos actores del sistema jurídico en sus conductas. En ese sentido, cambios jurisprudenciales radicales, como el anteriormente descrito, afectan la capacidad de los actores del sistema - los Estados- para ordenar sus propias actuaciones en conformidad al derecho. De allí que el Estado de derecho exija que "las distintas formas de derecho [...] [se] interpret[en] o apli[quen] de acuerdo con métodos interpretativos uniformes". ${ }^{71}$

\subsection{La apertura de procesos penales fenecidos}

La Corte IDH reconoció como derecho implícito dentro de la Convención el derecho a la verdad y a la sanción penal efectiva. Ello en el contexto de las violaciones masivas de los derechos humanos cometidas durante dictaduras militares en el continente. Esto llevó a la Corte a declarar contrarias a la Convención y nulas $a b$ initio una serie de amnistías dictadas por esos gobiernos y por otros gobiernos de naturaleza autoritaria durante o al término de sus periodos. El principal argumento al respecto era que esos gobiernos habian dictado autoamnistías destinadas a evitar la persecución penal, lo que era contrario al artículo 25 de la Convención. ${ }^{72}$ Sin embargo, la Corte también aplicó la misma regla respecto de amnistías dictadas por parlamentos democráticamente elegidos tras el término de estos regímenes autoritarios y confirmadas a través de plebiscitos democráticamente realizados. ${ }^{73}$ Aún más, la Corte ha especificado que incluso las normas de prescripción penal ordinarias serian contrarias a la Convención cuando las mismas impidieran la persecución penal de un delito que lleva aneja la infracción de derechos humanos. ${ }^{74}$

En ese contexto, la Corte IDH, en la misma sentencia que ordena dejar sin efecto la amnistía, ordena la reapertura de procesos penales concluidos con autoridad de cosa juzgada en contra de quienes resulten responsables por la comisión de delitos que impliquen la violación de derechos humanos fundamentales. Ello ocurrió, por ejemplo, con Chile tras la sentencia del caso Almonacid vs. Chile (2006), en la cual la Corte ordenó la reapertura de los procesos penales fenecidos debido

71 Robert Summers, "Los principios del estado de derecho", op. cit., p. 40.

72 Corte IDH, "Caso Almonacid Arellano y otros vs. Chile. Excepciones Preliminares, Fondo, Reparaciones y Costas”, cit., párrafos 123-128.

73 Corte IDH, “Caso Gelman vs. Uruguay. Fondo y Reparaciones”, cit., párrafo 238.

74 Corte IDH, "Caso Bulacio vs. Argentina. Fondo, Reparaciones y Costas", Sentencia de 18 de Septiembre de 2003, Serie C No. 100, 2003, párrafo 116. 
a la aplicación de la ley de amnistía. ${ }^{75} \mathrm{El}$ responsable del delito en específico fue juzgado nuevamente y, al final, sancionado penalmente. ${ }^{76}$

En primer lugar, aparece como encomiable el deseo de la Corte IDH de evitar la impunidad en Latinoamérica respecto de crimenes que involucren la violación masiva de derechos humanos fundamentales; es perfectamente entendible el deseo de justicia que subyace tras esta linea jurisprudencial. Sin embargo, esta forma de hacer justicia entra, al menos, en conflicto con un elemento central de todo Estado de derecho: la irretroactividad y el principio del non bis in idem.

Dicha tensión incluso ha sido reconocida por tribunales nacionales, como la Corte Suprema de Uruguay. Dicha Corte, conociendo de un recurso de inconstitucionalidad, declaró que la reapertura de procesos penales entonces cerrados con fuerza de cosa juzgada era contraria no solo a las normas de la constitución nacional, sino también al artículo 9 de la Convención Americana. Ello aun cuando los delitos investigados tenían relación con crimenes cometidos durante la dictadura militar uruguaya. ${ }^{77}$

Es importante perseguir delitos que impliquen violaciones flagrantes de derechos humanos. Sin embargo, el Estado de derecho nos dice que esa persecución penal debe hacerse conforme a ciertos principios que limitan la discrecionalidad de la actuación estatal.

\subsection{La creación del control de convencionalidad}

La Corte IDH ha desarrollado por vía jurisprudencial la doctrina del denominado control de convencionalidad. A través de esta doctrina, la Corte ha otorgado facultades a los tribunales nacionales de los Estados para, de conformidad con los procedimientos internos de cada uno, revisar la convencionalidad de las leyes al momento de que estas sean aplicadas. ${ }^{78}$ Adicionalmente, la Corte ha señalado que dicho control debe ser ejercido de acuerdo con el entendimiento que la propia Corte IDH tiene del texto de la Convención. ${ }^{79}$ Este sistema, en la práctica, genera un modelo de revisión centralizado, en el cual las cortes nacionales deben someter su análisis de convencionalidad a aquello dispuesto por la Corte IDH, la que pasa a ocupar la cúspide jerárquica dentro de este sistema.

La creación de este control por vía jurisprudencial genera otra tensión importante respecto de un factor esencial para el Estado de derecho: el principio de legali-

75 Corte IDH, "Caso Almonacid Arellano y otros vs. Chile. Excepciones Preliminares, Fondo, Reparaciones y Costas", cit., párrafo 145.

76 Gonzalo Aguilar Carvallo, “'Afinando las 'cuerdas' de la especial articulación entre el derecho internacional de los derechos humanos y el derecho interno”, Estudios Constitucionales, 11 (1) (2013), pp. 633-654.

77 Corte Suprema de Uruguay, AA.VV. Denuncia. Excepción de Inconstitucionalidad artículos 1,2 y

24478 Corte IDH, "Caso Almonacid Arellano y otros vs. Chile. Excepciones Preliminares, Fondo, Reparaciones y Costas”, cit., párrafo 124.

79 Ibid., párrafo 124

DÍKAION - ISSN 0120-8942 
dad. En efecto, no existe norma alguna que habilite expresamente a la Corte IDH a otorgar dichos poderes de revisión a los tribunales nacionales. Tampoco existe disposición alguna dentro de la Convención que permita a la Corte alterar la naturaleza del sistema de control de revisión de convencionalidad en el continente generando un sistema de precedente obligatorio respecto de los Estados. De hecho, el artículo 68.1 de la Convención señala que los Estados se comprometen a cumplir aquellas decisiones en que los mismos sean partes, sin perjuicio de la natural deferencia que los tribunales nacionales puedan mostrar hacia una jurisdicción especializada como la Corte IDH.

La generación por parte de la Corte IDH de un mecanismo de control de la magnitud del control de convencionalidad es claramente dificil de compatibilizar con el principio de legalidad, cuyo respeto siempre ha promovido la Corte respecto de los Estados. La propia Corte no ha ignorado esta preocupación tan propia del Estado de derecho de mantener a las instituciones dentro de sus competencias. De hecho, la Corte señaló tempranamente que si bien la función principal del sistema de protección de derechos a nivel continental era custodiar los derechos humanos, los mecanismos asociados a ello eran aquellos respecto de los cuales los propios Estados habian entregado su consentimiento. ${ }^{80}$ Por tanto, la labor de la Corte era "garantizar la protección internacional que establece la Convención [respecto de los derechos] dentro de la integridad del sistema pactado por los Estados". ${ }^{81}$ De allí que la actividad de la Corte IDH debía buscar la promoción de los derechos humanos "siempre que ello no impli[cara] una alteración del sistema". ${ }^{82}$

Ahora bien, existen otros factores adicionales asociados al control de convencionalidad que generan tensiones con elementos propios del Estado de derecho. Dichos factores están asociados a los modos de legislación judicial, que muchas veces carecen de la claridad de la norma legal.

Por ejemplo, la única regulación procedimental del control de convencionalidad ha sido generada a partir del voto concurrente del destacado juez Eduardo FerrerMcGregor. ${ }^{83}$ Pese a la profundidad de su trabajo, los actores del sistema no disponen de claridad suficiente acerca de cómo el control de convencionalidad debe ser articulado dentro de mecanismos de revisión judicial centralizada, en la que existe un solo tribunal llamado a declarar la inconstitucionalidad de una norma legal. Dentro de ese esquema, ¿cuál es la autoridad de la que disponen los demás jueces? O bien, ¿cuál es la autoridad de la cual goza la autoridad política o legislativa para efectuar el control? ¿Qué ocurre si existen desacuerdos en la doctrina de la Corte IDH respecto de un precedente? ¿Quién lo interpreta? ¿Cuál es la sanción que debe acompañar la sentencia que afirma la infracción de la

80 Corte IDH, “Asunto de Viviana Gallardo y otras”, Sentencia del 13 de noviembre de 1981, Serie A No. 101, 1981, párrafo 16.

81 Ibid., párrafo 16.

82 Idem.

83 Corte IDH, "Caso Cabrera García y Montiel Flores vs. México. Excepción Preliminar, Fondo, Reparaciones y Costas. Voto concurrente del juez Eduardo Ferrer-McGregor", Sentencia de 26 de noviembre de 2010, Serie C No. 220, 2010. 
Convención?, ¿inexistencia o nulidad? ¿Qué ocurre con los actos ejecutados en el tiempo intermedio?, ¿generan derechos para los beneficiarios? Todas esas preguntas requieren de una respuesta relativamente univoca y clara.

Existen muchas cuestiones abiertas que impiden a las autoridades judiciales nacionales orientar su conducta con grados de certeza compatibles con la relevancia de la temática en cuestión. Ello genera, a todas luces, una nueva tensión respecto de los elementos que configuran el Estado de derecho.

\subsection{La disponibilidad del recurso de revisión}

El artículo 67 de la Convención señala que los fallos de la Corte IDH son "definitivos e inapelables". Por tanto, en principio, pareciera que solo cabe respecto de aquellos el recurso de interpretación, que el mismo artículo 67 permite en aquellos casos en que exista "desacuerdo sobre el sentido o alcance del fallo".

Sin embargo, la Corte IDH ha entendido que de acuerdo con las reglas generales del derecho procesal, el recurso de revisión —entendido este como un mecanismo extraordinario- seria procedente en casos excepcionales, en los cuales se haga presente a la Corte "hechos o situaciones relevantes desconocidas en el momento de dictarse la sentencia”. ${ }^{44}$ En ese mismo sentido, la Corte IDH manifestó que "es admisible el recurso de revisión en casos excepcionales, cuando un hecho, conocido luego de emitida la sentencia, afecte lo decidido, o demuestre un vicio sustancial de esta”. ${ }^{85}$

Pese a lo anteriormente señalado, la propia Corte alteró su jurisprudencia uniforme en torno a la procedencia del recurso de revisión en la resolución de supervisión de cumplimiento de la sentencia del caso de la Masacre de Mapiripán vs. Colombia (2005). ${ }^{86}$ En dicha resolución, y frente a un recurso de revisión planteado por el Estado colombiano, la Corte IDH declaró sencillamente que dicho recurso no era procedente respecto de las sentencias de la Corte en la medida que el artículo 67 de la Convención establecía que sus fallos eran "definitivos e inapelables".

Desde una perspectiva estrictamente jurídica, es posible discutir acerca de la procedencia o no del recurso de revisión a la luz de lo dispuesto en el artículo 67 de la Convención. ${ }^{87}$ Sin embargo, una vez que la Corte IDH adoptó una línea jurisprudencial en torno a este tema, esta debe ser mantenida en términos generales. Ello porque este es el único camino que permite orientar la conducta de quienes

84 Corte IDH, “Caso Genie Lacayo vs. Nicaragua. Fondo, Reparaciones y Costas”, Sentencia de 29 de enero de 1997, Serie C No. 30, 1997, párrafo 12.

85 Corte IDH, "Caso Juan Humberto Sánchez vs. Honduras. Excepción Preliminar, Fondo, Reparaciones y Costas", cit., párrafo 115 .

86 Corte IDH, "Caso de la Masacre de Mapiripán vs. Colombia. Supervisión de Cumplimiento de Sentencia”, Resolución de la Presidenta de Corte Interamericana de Derechos Humanos de 26 de noviembre de 2008.

87 Para un análisis de la cuestión véase: Álvaro PAÚl Díaz, "Giro en materia de recurso de revisión ante la Corte Interamericana”, Revista Chilena de Derecho y Ciencia Política, 4 (2) (2013) pp. 131-138. 
litigan ante esta alta magistratura. Esto es una exigencia cierta del Estado de derecho: la jurisprudencia de las cortes debe propender por generar certezas dentro del sistema, de tal forma que los interesados puedan planificar su conducta a largo plazo. Pareciera que la vacilante jurisprudencia de la Corte IDH en torno a esta materia no aporta a ese propósito.

\section{CORTE IDH Y ESTADO DE DERECHO: ¿HACIA DÓNDE AVANZAR?}

Tal como se señaló, la Corte IDH tiene una visión concreta acerca del significado y la importancia de los elementos que configuran la noción de Estado de derecho. De hecho, en función de esos elementos ha condenado a los Estados ante la infracción de la legalidad, la irretroactividad y el debido proceso. Sin embargo, y tal como se ha indicado en este trabajo, la Corte ha generado lineas jurisprudenciales que evidentemente crean una tensión con los elementos del Estado de derecho que la propia reconoce como fundamentales.

Ante esta problemática, la propuesta de solución es la siguiente: la Corte IDH debe aplicar respecto de su actuación interpretativa y creadora los elementos que ella misma ha definido como esenciales para el Estado de derecho en relación con los Estados. En ese sentido, es esencial que la Corte siga promoviendo la defensa de los derechos humanos en el continente de acuerdo con los elementos que configuran el Estado de derecho.

Para que ello ocurra, parece necesario que la Corte y todos los demás actores del sistema interamericano - la Comisión Interamericana de Derechos Humanos y los Estados partes de la Convención- profundicen en torno a las demandas del Estado de derecho y los valores sustantivos que ellas promueven, como lo son el respeto por la dignidad de las personas, su libertad e igualdad ante el derecho.

Ahora bien, tratándose de la Corte IDH, esa profundización en torno a los elementos del Estado de derecho exigirá, en muchos casos, que este tribunal ejerza sus potestades con altos grados de disciplina interna y self-restraint. Quizá para muchos el que ello ocurra resulta dificil, especialmente en el contexto de las nuevas líneas jurisprudenciales que la Corte IDH ha adoptado y que han sido descritas a lo largo del trabajo. Sin embargo, ello no debe ser necesariamente así. La Corte también ha aprendido a ejercer grados de self-restraint en ciertas áreas claves para la promoción del Estado de derecho.

Considérese, por ejemplo, la sentencia de la Corte IDH que resolvió las excepciones preliminares planteadas por el Estado colombiano en el caso Las Palmeras vs. Colombia (2000). ${ }^{88}$ En este caso, la Comisión Interamericana de Derechos Humanos acusó a Colombia ante la Corte por la ejecución extrajudicial de seis civiles

88 Corte IDH, “Caso Las Palmeras vs. Colombia. Excepciones previsionales”, Sentencia de 4 de febrero de 2000 , Serie C No. $67,2000$. 
por parte de sus fuerzas armadas y su policía en el contexto de la lucha contra la guerrilla. En el petitorio de la demanda presentada por la Comisión, se pedía que la Corte condenara al Estado por la violación del artículo 3 común de las Convenciones de Ginebra de 1949. En ese contexto, Colombia presentó excepciones preliminares, una de las cuales tenía por objeto que la Corte IDH declarara su falta de competencia para aplicar las Convenciones de Ginebra.

La Corte IDH resolvió la petición en favor del Estado colombiano. En efecto, la Corte concluyó que sus atribuciones, de acuerdo con el artículo 62.3 de la Convención Americana, tenían por objeto "conocer de cualquier caso relativo a la interpretación y aplicación” de las disposiciones del tratado. ${ }^{89}$ Por tanto, la Convención "solo ha atribuido competencia a la Corte para determinar la compatibilidad de los actos o de las normas de los Estados con la propia Convención, y no con los Convenios de Ginebra de 1949".90

Este fallo revela claramente un apego estricto por parte de la Corte IDH a los principios elementales que configuran el Estado de derecho: legalidad e irretroactividad. En efecto, la Corte ejerció altos grados de disciplina interna al resolver las excepciones preliminares en el caso Las Palmeras y decidió mantener su actuación dentro del ámbito de la legalidad del sistema interamericano. Si bien el argumento central de la Corte IDH para operar de esa forma fue el texto del artículo 62.3 de la Convención, es posible entender que detrás de ese fallo estuvo también presente el anhelo de la Corte de preservar los valores de la legalidad (apego al texto de la Convención) y la irretroactividad (los Estados no pueden ser juzgados y condenados por dejar de cumplir en el pasado obligaciones cuya existencia era ignorada). Como es posible apreciar, la Corte efectivamente entiende la importancia del Estado de derecho para el correcto funcionamiento del sistema interamericano. Lo exhibido en Las Palmeras muestra una Corte capaz de respetar la legalidad del sistema interamericano en el ejercicio de sus competencias. De alli que la solución a la problemática de Estado de derecho generada por la Corte IDH en las diversas líneas jurisprudenciales descritas en este artículo se encuentre, precisamente, en la doctrina y jurisprudencia que la propia Corte ha pronunciado en relación con la necesidad de preservar el principio de legalidad y la prospectividad de las normas jurídicas. La decisión de la Corte IDH en Las Palmeras nos demuestra que ello es, efectivamente, posible.

\section{CONCLUSIÓN}

Es indudable que la Corte IDH ha sido un instrumento fundamental para la promoción de los valores del Estado de derecho dentro de los Estados. Ello en la medida que algunas de sus sentencias a) conceptualizan positivamente los principios de legalidad e irretroactividad, y b) les ofrecen protección efectiva frente a infracciones de los Estados. 
Sin embargo, es posible advertir la existencia de ciertas lineas jurisprudenciales de la Corte IDH que crean tensiones severas con elementos propios del Estado de derecho que la misma Corte ha reconocido como esenciales para la pervivencia de un sistema jurídico justo. Esas tensiones emergen en materias como la doctrina de los derechos implícitos, la protección del derecho a la vida, la reapertura de procesos penales, la creación del control de convencionalidad y la disponibilidad del recurso de revisión. Dichas tensiones solo pueden ser aliviadas mediante el reforzamiento de la comprensión de la noción de estado de derecho y sus elementos fundamentales por parte de la Corte IDH.

\section{BIBLIOGRAFÍA}

Aguilar, Gonzalo “'Afinando las cuerdas' de la especial articulación entre el derecho internacional de los derechos humanos y el derecho interno", Estudios Constitucionales, 11 (1) (2013), pp. 633-654.

Ayala, Carlos, "La ejecución de sentencias de la Corte Interamericana de Derechos Humanos”, Estudios Constitucionales, año 5 (1) (2007), pp. 127-201.

Besson, Samantha, "Theorizing the sources of international law", en Samantha Besson y John Tasioulas (eds.), The philosophy of international law, Oxford, Oxford University Press, 2012, pp.163-185.

Burgorgue-Larsen, Laurence, "El contexto, las técnicas y las consecuencias de la interpretación de la Convención Americana de Derechos Humanos”, Estudios Constitucionales, año 12 (1) (2014), pp. 105-106.

CANDIA, Gonzalo, "Derechos implicitos y Corte Interamericana de Derechos Humanos: una reflexión a la luz de la noción de estado de derecho”, Revista Chilena de Derecho, 42 (3) (2015), pp. 873-902.

CAssese, Antonio, International Law, Oxford, Oxford University Press, 2005.

Chesterman, Simon, “An international rule of law?”, American Journal of Comparative Law, 56 (2008), pp. 331-362.

Crawford, James, "International law and the rule of law", Adelaide Law Review, 24 (3) (2003), pp. 3-12

D’Aspremont, Jean, Formalism and the sources of international law, Oxford, Oxford University Press, 2011.

Dicey, Albert Venn, Introduction to the Study of the Constitution, 8 ed., Indianapolis, Liberty Fund, 1982.

FinNis, John, Natural Law and Natural Rights, Oxford, Oxford University Press, 2 ed., 2011.

Fuller, Lon, The Morality of Law, 2 ed., New Haven, Yale University Press, 1964.

GILBerT, Guillaume, "The Profileration of International Judicial Bodies: The Outlook for the International Legal Order", Corte Internacional de Justicia, 2000, en: http://www.icj-cij.org/court/index.php?pr=85\&pt=3\&p1=1\&p2=3\&p3=1. 
Gros Espiell, Héctor, "Los derechos humanos no enunciados o no enumerados en el constitucionalismo americano y en el artículo 29.c) de la Convención Americana sobre Derechos Humanos”, Anuario Iberoamericano de Justicia Constitucional, 4 (2000), pp. 145-172.

Hart, H.L.A., The Concept of Law, 2 ed., Oxford, Oxford University Press, 1994.

Kumm, Mattias, "The international rule of law and the limits of the internationalist model”, Virginia Journal of International Law, 44 (2003-2004), pp. 19-32.

PAÚl DíAz, Álvaro, "Giro en materia de recurso de revisión ante la corte interamericana”, Revista Chilena de Derecho y Ciencia Politica, 4 (2) (2013), pp. 131-138.

Medina, Cecilia, "The role of international tribunals: law-making or creative interpretation", en Dinah SHELTon (ed.), The Oxford Handbook of International Human Rights Law, Oxford, Oxford University Press, 2013, pp. 649-669.

RAZ, Joseph, "The rule of law and its virtue", en Joseph RAZ (autor), The authority of law, 2 ed., Oxford, Oxford University Press, 2009, pp. 210-229.

Rodríguez, Gabriela, "Artículo 30. Alcance de las restricciones", en Christian SteINER y Patricia URIBE (eds.), Comentario Convención Americana sobre Derechos Humanos, Bolivia, Konrad Adenauer Stiftung, 2014, pp. 715-718.

Soтo-Kloss, Eduardo, Derecho Administrativo-Bases Fundamentales, Santiago de Chile, Editorial Jurídica de Chile, t. II, 1996.

WALDRON, Jeremy, "The rule of international law", Harvard Journal of Law \& Public Policy, 30 (1) (2006), pp. 15-30.

WALDRON, Jeremy, "Are sovereign entitled to the benefit of the international rule of law?”, The European Journal of International Law, 22 (2) (2011), pp. 315-343.

WALDRON, Jeremy, "The rule of law and the importance of procedure", en James E. Fleming (ed.), Getting to the rule of law, New York, New York University Press, 2011, pp. 3-31.

WATTS, Arthur, "The international rule of law", German Yearbook of International Law, 36 (1993), pp. 15-45.

\section{JURISPRUDENCIA CITADA}

Corte IDH, "Asunto de Viviana Gallardo y otras", Sentencia del 13 de noviembre de 1981, Serie A No. 101, 1981.

Corte IDH, "Caso Almonacid Arellano y otros vs. Chile. Excepciones Preliminares, Fondo, Reparaciones y Costas”, Sentencia de 26 de septiembre de 2006, Serie C No. 154, 2006.

250 Corte IDH, "Caso Apitz Barbera y otros ("Corte Primera de lo Contencioso Administrativo") vs. Venezuela. Excepción Preliminar, Fondo, Reparaciones y Costas”, Sentencia de 5 de agosto de 2008, Serie C No. 182, 2008. 
Corte IDH, "Caso Artavia Murillo y otros (Fecundación in vitro) vs. Costa Rica. Excepciones Preliminares, Fondo, Reparaciones y Costas”, Sentencia de 28 noviembre de 2012, Serie C No. 257, 2012.

Corte IDH, "Caso Baena Ricardo y otros Vs. Panamá. Fondo, Reparaciones y Costas”, Sentencia de 2 de febrero de 2001, Serie C No. 72, 2001.

Corte IDH, “Caso Bulacio vs. Argentina. Fondo, Reparaciones y Costas”, Sentencia de 18 de Septiembre de 2003, Serie C No. 100, 2003.

Corte IDH, “Caso Cabrera García y Montiel Flores vs. México. Excepción Preliminar, Fondo, Reparaciones y ------", Sentencia de 26 de noviembre de 2010 , Serie C No. 220, 2010.

Corte IDH, “Caso Castillo Páez vs. Perú. Fondo”, Sentencia de 3 de noviembre de 1997, Serie C No. 34, 1997.

Corte IDH, "Caso Castillo Petruzzi y otros vs. Perú. Fondo, Reparaciones y Costas”, Sentencia de 30 de mayo de 1999, Serie C No. 52, 1999.

Corte IDH, "Caso de la "Masacre de Mapiripán” vs. Colombia”, Sentencia de 15 de septiembre de 2005, Serie C No. 134, 2005.

Corte IDH, "Caso de la Comunidad Mayagna (Sumo) Awas Tingni vs. Nicaragua. Fondo, Reparaciones y Costas”, Sentencia de 31 de agosto de 2001, Serie C No. 79, 2001.

Corte IDH, “Caso de la Masacre de Mapiripán vs. Colombia. Supervisión de Cumplimiento de Sentencia”, Resolución de la Presidenta de Corte Interamericana de Derechos Humanos de 26 de noviembre de 2008.

Corte IDH, "Caso de los "Niños de la Calle” (Villagrán Morales y otros) vs. Guatemala. Fondo”, Sentencia de 19 de noviembre de 1999, Serie C No. 63, 1999.

Corte IDH, "Caso Fermin Ramírez vs. Guatemala. Fondo, Reparaciones y Costas”, Sentencia de 20 de junio de 2005, Serie C No. 126, 2005.

Corte IDH, "Caso Fermin Ramirez vs. Guatemala. Fondo, Reparaciones y Costas", Sentencia de 20 de junio de 2005, Serie C No. 126, 2005.

Corte IDH, "Caso Furlan y Familiares vs. Argentina. Excepciones Preliminares, Fondo, Reparaciones y Costas”, Sentencia de 31 de agosto de 2012, Serie C No. 246, 2012.

Corte IDH, "Caso García Asto y Ramírez Rojas vs. Perú”, Sentencia de 25 de noviembre de 2005, Serie C No. 137, 2005.

Corte IDH, “Caso Gelman vs. Uruguay. Fondo y Reparaciones”, Sentencia de 24 de febrero de 2011, Serie C No.221, 2011.

Corte IDH, "Caso Genie Lacayo us. Nicaragua. Fondo, Reparaciones y Costas", Sentencia de 29 de enero de 1997, Serie C No. 30, 1997.

Corte IDH, "Caso Juan Humberto Sánchez vs. Honduras. Excepción Preliminar, Fondo, Reparaciones y Costas”, Sentencia de 7 de junio de 2003, Serie C No. 99, 2003. 
Corte IDH, “Caso Kimel vs. Argentina. Fondo, Reparaciones y Costas”, Sentencia de 2 de mayo de 2008, Serie C No. 177, 2008.

Corte IDH, "Caso Kimel vs. Argentina. Fondo, Reparaciones y Costas", Sentencia de 2 de mayo de 2008, Serie C No. 177, 2008.

Corte IDH, "Caso López Álvarez vs. Honduras. Fondo, Reparaciones y Costas", Sentencia de 1 de febrero de 2006, Serie C No. 141, 2006.

Corte IDH, "Caso Montero Aranguren y otros (Retén de Catia) vs. Venezuela. Excepción Preliminar, Fondo, Reparaciones y Costas”, Sentencia de 5 de julio de 2006, Serie C No. 150.

CoRTE IDH, "Caso Salvador Chiriboga vs. Ecuador. Excepción preliminar y Fondo", Sentencia de 6 de mayo de 2008, Serie C No. 179, 2008.

Corte IDH, "Caso Torres Millacura y otros vs. Argentina. Fondo, Reparaciones y Costas”, Sentencia de 26 de agosto de 2011, Serie C No. 229, 2011.

Corte IDH, "Caso Tristán Donoso vs. Panamá, Excepción Preliminar, Fondo, Reparaciones y Costas”, Sentencia de 27 de enero de 2009, Serie C No. 193, 2009.

Corte IDH, "Caso Usón Ramírez vs. Venezuela. Excepción Preliminar, Fondo, Reparaciones y Costas”, Sentencia de 20 de noviembre de 2009, Serie C No. 207, 2009.

Corte IDH, “Caso Usón Ramírez vs. Venezuela. Excepción Preliminar, Fondo, Reparaciones y Costas”, Sentencia de 20 de noviembre de 2009, Serie C No. 207, 2009.

Corte IDH, “Caso Velásquez Rodríguez vs. Honduras. Fondo”, Sentencia de 29 de julio de 1988, Serie C No. 4, 1988.

Corte IDH, "Caso Velásquez Rodríguez vs. Honduras. Fondo”, Sentencia de 29 de julio de 1988, Serie C No. 4, 1988.

Corte IDH, “Caso Velásquez Rodríguez vs. Honduras. Fondo”, Sentencia de 29 de julio de 1988, Serie C No. 4, 1988.

CorTe IDH, "El Hábeas Corpus Bajo Suspensión de Garantias (arts. 27.2, 25.1 y 7.6 Convención Americana sobre Derechos Humanos)”, Opinión Consultiva OC-8/87 del 30 de enero de 1987, Serie A No. 8, 1987.

Corte IDH, "La Expresión 'Leyes' en el artículo 30 de la Convención Americana sobre Derechos Humanos", Opinión Consultiva OC-6/86 del 9 de mayo de 1986, Serie A No. 6, 1986.

Corte Suprema de Uruguay, AA.VV. Denuncia. Excepción de Inconstitucionalidad Artículos 1, 2 y 3 de la Ley N 18.831, IUE 2-109.9717/2011 (2013). 